\title{
PESANTREN MENEMBUS BATAS \\ (Studi Kapital Spiritual-Multikultural Pesantren Al-Qodir dalam Membentuk Santri Multikulturalis )
}

\author{
Sauqi Futaqi \\ Universitas Islam Darul Ulum Lamongan \\ Email : sauqifutaqi@gmail.com
}

\begin{abstract}
Abstrak
Penelitian ini mengkaji tentang kapital spiritual pesantren yang digunakan sebagai basis utama dalam membentuk santri multikulturalis. Dengan adanya kapital ini, pesantren Al-Qodir mampu menembus sekat-sekat kultural dan agama, sehingga memungkinkan pesantren bisa terbuka untuk semua golongan. Melalui studi fenomonologi dengan pengumpulan data melalui observasi, wawancara, dan dokumentasi, penelitian ini bertujuan untuk menemukan kapital spiritual dan pendayagunaannya dalam membangun kesadaran multikultural. Dari hasil penelitian, ada beberapa temuan penting: 1) spiritualitas Kiai memungkinkan terjadinya keterbukaan pesantren; 2) adanya integrasi spiritual dan multikultural yang melahirkan pandangan bahwa multikulturalisme sebagai spiritualitas; 3) 2) nilai-nilai spiritual merupakan nilai pembentuk nilai-nilai multikultural; 4) adanya pemahaman akan tujuan beragama sebagai kebertuhanan dan kemanusiaan; 5) kapital spiritual-multikultural tersebut menjadi basis utama dalam membentuk santri multikulturalis.
\end{abstract}

Kata kunci: kapital, spiritual-multikultural, nilai spiritual-multikultural, santri multikulturalis

\section{Abstract}

This study examines the spiritual capital of pesantren which is used as the main basis in forming multiculturalist santri. With this capital, the Al-Qodir pesantren is able to penetrate cultural and religious barriers, thus allowing pesantren to be open to all groups. Through phenomonology studies by collecting data through observation, interviews, and documentation, this research aims to find spiritual capital and its utilization in building multicultural awareness. From the results of the study, there are several important findings: 1) Kiai's spirituality enables the opening of pesantren; 2) the existence of spiritual and multicultural integration which gave birth to the view that multiculturalism as spirituality; 3) 2) spiritual values are the values forming multicultural values; 4) there is an understanding of the purpose of religion as Godliness and humanity; 5) the spiritual- 
PESANTREN MENEMBUS BATAS (Studi Kapital Spiritual-Multikultural Pesantren Al-Qodir dalam Membentuk Santri Multikulturalis ) (Sauqi Futaqi)

multicultural capital becomes the main base in forming multiculturalist santri.

Keywords: multicultural spiritual-capital, spiritual-multicultural value, santri multiculturalist

\section{PENDAHULUAN}

Ide penelitian tentang kapital spiritual berangkat dari pengalaman peneliti ketika berkunjung dan berinteraksi dengan Kiai dan beberapa santri di Pesantren al-Qodir. Setelah beberapa kali berkunjung kesana, ada satu pemandangan menarik bahwa pesantren ini seringkali ditempati oleh komunitas lain yang beragam, mulai dari komunitas lintas agama, lintas seni dan budaya. Selain ditempati komunitas yang berbeda, pesantren ini juga sering mengadakan kegiatan yang bersifat multikultural.

Salah satu contoh dan ini merupakan pemandangan yang jarang ditemui di pesantren pada umumnya bahwa para santri Al-Qodir turut hadir dan merayakan peresmian Gereja Katolik St. Fransiskus Xaverius Cangkringan pada tanggal 28 November 2013. Selain penampilan dari kelompok Jatilan dan Wayangan, para santri juga menampilkan seni Hadroh yang beranggotakan sekitar 30 santri. Sebelumnya, tahun 2012, para santri al-Qodir juga turut pada acara "Karnaval Perdamaian", dengan melakukan perjalanan dari tugu Yogyakarta sampai Malioboro. ${ }^{1}$ Sebagaimana yang diakui salah satu informan, "Disana ada Islam, Kristen, Khonghucu, Hindu, Budha, ikut semua, yang dari Islam cuma dari pesantren sini. Kita di baris paling depan sendiri, memakai sarung."

Tindakan tersebut bisa terjadi karena adanya modal spiritual yang dimiliki pesantren. Mbah Masrur (sapaan akrabnya) merupakan pengasuh yang cenderung menampilkan karakter kesufian. Secara personal Kiai sendiri cenderung menganggap spiritualitas sebagai basis utama dalam menyikapi keragaman. "Kalau saya, tentang kebersamaan, tentang perbedaan, itu bukan karena tingginya pengetahuan. Tapi karena spiritualitas. Semakin tinggi pengetahuan, terkadang suka menyalahkan orang, merasa paling benar. Semakin tinggi spiritual, semakin melebur dengan kehidupan."

Beberapa fenomena yang dialami pesantren tersebut memberikan pemahaman bahwa pesantren sebagai lembaga pendidikan keagamaan memiliki basis spiritual yang kuat. Mereka tidak lagi memiliki kekhawatiran secara teologis ketika berhadapan dengan komunitas non-muslim. Ini sesuai dengan beberapa penuturan santri bahwa pesantren Al-Qodir cenderung

\footnotetext{
${ }^{1}$ Wawancara dengan Pengurus Pusat Pesantren Al-Qodir/(02/W/17/XI/2017)

${ }^{2}$ Wawancara dengan Pengurus Pusat Pesantren Al-Qodir pada 17 November 2017

${ }^{3}$ Wawancara dengan KH Masrur Ahmad, Pada Tanggal 7 Juli 2018
} 
mengedepankan spiritualitas daripada intelektualitas. Beberapa praktek pendidikan lebih ditonjolkan pada aspek sikap batin santri dengan ilmu hikmah sebagai basisnya. Oleh karena itu, peneliti tertarik untuk mendalami kapital spiritual pesantren, karena dalam pandangan pesantren spritualitas merupakan modal utama dalam membangun kesadaran multikultural.

Kajian ini akan difokuskan pada dua hal. Pertama, kapital spiritual pesantren yang meliputi, pengamalan spiritual, nilai spiritual, dan penghayatan spiritual. Kedua, kesadaran multikultural santri sebagai implikasi dari kapital spiritual yang dimiliki pesantren. Kajian ini diharapkan dapat memberikan informasi dan temuan yang bersifat praktis dan teoritis. Hal ini mengingat teori kapital spiritual yang diintegrasikan dengan teori multikultural masih belum banyak dikaji oleh para peneliti.

\section{METODE PENELITIAN}

Dalam melakukan penelitian tentang kapital spiritual-multikultural pesantren Al-Qodir, peneliti menggunakan pendekatan fenomenologi karena dianggap relevan dengan kajian spiritual. Dalam mengumpulkan data, peneliti akan melihat lebih banyak pengalaman seseorang karena spiritualitas sangat berkaitan dengan sikap batin seseorang. Maka, peneliti akan bergerak terutama pada wawancara, yang selanjutnya diperkuat dengan beberapa kegiatan di pesantren. Tentu saja peneliti berlama-lama di pesantren untuk menyelami kehidupan Kiai, Utadz, dan santri. Selain dua hal yang pokok, peneliti juga mencoba melihat beberapa dokumen yang berkaitan dengan bukti-bukti adanya spiritualitas, seperti pelayanan terhadap komunitas non-muslim dan beberapa kegiatan santri di rumah ibadah agama lain. Beberapa data tersebut akan menggambarkan saat-saat dan makna keseharian dalam kehidupan orang-orang yang berada didalamnya, ${ }^{4}$ sehingga kepemilikan kapital spiritual pesantren dapat terungkap secara holistik dan komprehensif.

Setelah data terkumpul, peneliti akan melakukan analisis. Dalam analisis situs tunggal ini, peneliti akan menggunakan langkah-langkah analisis data yang ditawarkan oleh John Cresswel. Menurut Cresswell, ada 6 (enam) langkah dalam analisis data kualitatif, yakni: 1) Mempersiapkan dan mengorganisasikan data untuk dianalisis; 2) Mengeksplorasi data dan mengode data; 3) Mengode data untuk membangun deskripsi dan tema; 4) Merepresentasikan dan melaporkan temuan penelitian; 5) Menginterpretasikan temuan; dan 6) Memvalidasi keakuratan temuan. ${ }^{5}$

${ }^{4}$ Norman K. Denzin \& Yvonna S. Lincoln, Handbook ofQualitative Research, terj. (Yogyakarta: Pustaka Pelajar, 2009), 2

5 John W. Creswell, Riset Pendidikan: Perencanaan, Pelaksanaan, dan Evaluasi Riset Kualitatif dan Kuantitatif, terj. (Yogyakarta: Pustaka Pelajar, 2015), 467-518 
Setelah dianalisis, peneliti berusaha memastikan penelitian tersebut koheren (coherency) dan memiliki konsistensi makna (consistency of meaning). ${ }^{6}$ Dalam melihat koherensi dan konsistensi makna tersebut, peneliti menggunakan metode trianggulasi, yang diantaranya trianggulasi data, peneliti, metodologis, dan teoritis. ${ }^{7}$ Keempat trianggulasi tersebut akan digunakan secara bergantian untuk menemukan keabsahan data.

\section{PEMBAHASAN}

\section{Kapital Spiritual-Multikultural}

Konsep kapital spiritual telah muncul di beberapa literatur, baik dalam bidang kepemimpinan dan manajemen, ekonomi, sosiologi, maupun dalam bidang teologis. Sementara jalur ini saling tumpang tindih, masingmasing menawarkan konseptualisasi yang berbeda dari kapital spiritual. Upaya untuk mengoperasionalkan kapital spiritual telah diterapkan pada tingkat yang berbeda, baik pada tingkat individu, organisasi, komunitas iman tertentu, dan komunitas atau bangsa yang lebih luas. ${ }^{8}$

Secara konseptual, para ahli mengartikan kapital spiritual secara beragam. Menurut Berger dan Redding, kapital spiritual adalah sebuah bentuk yang berkaitan dengan iman, transendensi, dan rasa memiliki. Kapital spiritual dianggap sebagai satu set sumber daya yang dapat diperoleh, diinvestasikan, diakumulasikan, digunakan untuk pertukaran dan keuntungan tertentu. ${ }^{9}$ Pada kesempatan lain, Berger dan Hefner melihat kapital spiritual mengacu pada kekuatan, pengaruh, pengetahuan, dan disposisi yang diciptakan oleh tradisi keagamaan tertentu. ${ }^{10}$ Dengan demikian, begitu juga Baker dan Skinner (2006), kapital spiritual memiliki hubungan dinamis dengan kapital keagamaan (religious capital) karena memberi energi dan menginformasikan kapital religius dengan memberikan identitas teologis dan tradisi pemujaan, namun juga sistem nilai, visi moral

6 Daniel Sousa, "Validation in Qualitative Research: General Aspects and Specificities of the Descriptive Phenomenological Method," in Qualitative research in Psychology, 11:211-2227, 2015.

${ }^{7}$ M. Djunaidi Ghony \& Fauzan Almansur, Metodologi Penelitian Kualitatif, cet. Ke-2 (Yogyakarta: Ar-ruz Media, 2017), 322-323.

${ }^{8}$ David A. Palmer and Michele Wong, "Clarifying the Concept of Spiritual Capital," Prepared for the Conference on the Social Scientific Study of Religion The Chinese University of Hong Kong, 10-13 July 2013.

9 Peter Berger and Gordon Redding. The Hidden Form of Spiritual Capital Influences in Societal Progress. (New York: Anthem Press, 2010), hlm. 138-139.

${ }^{10}$ Peter L. Berger and Robert W. Hefner (2003), "Spiritual Capital in Comparative Perspective," Conference Paper, Diakses pada tanggal 3 Maret 2018 dari http://www.metanexus.net/spiritual_capital/pdf/Berger.pdf 
dan dasar iman. ${ }^{11}$ Sedangkan kapital keagamaan adalah dimensi yang solid yang terdiri dari tindakan dan sumber nyata yang diakui oleh komunitas iman sebagai akibat langsung dari kapital spiritual mereka. ${ }^{12}$

Selain para ahli di atas, Zohar dan Marshall mengartikan kapital spiritual sebagai jumlah pengetahuan dan keahlian spiritual yang tersedia bagi individu, kelompok atau budaya, di mana konsep spiritual berarti makna, nilai, dan tujuan mendasar. Ini mengacu pada sumber daya yang lahir dari spirit manusia, berbagi makna, tujuan bersama, berbagi visi tentang hal-hal yang paling penting dalam kehidupan - dan bagaimana hal ini diterapkan dalam kehidupan dan perilaku keseharian mereka. ${ }^{13}$

Berbicara kapital spiritual, perju juga pemahaman spiritualitas dalam Islam. Esensi spiritualitas, sebagaimana dikemukakan Nasr, adalah realisasi Kesatuan, seperti yang diungkapkan dalam Al-Quran, atas dasar model kenabian dan dengan bantuan Nabi. Tujuan dari spiritualitas ini adalah untuk menjadi diperindah oleh Kualitas Ilahi melalui pencapaian kebajikankebajikan yang dimiliki dalam kesempurnaan mereka oleh Nabi dan dengan bantuan metode dan rahmat yang mengeluarkan darinya dan Wahyu AlQuran. ${ }^{14}$ Kehidupan spiritual didasarkan pada rasa takut akan Tuhan dan ketaatan kepada kehendak-Nya. Spiritualitas Islam adalah realisasi cinta yang didasarkan oleh pengetahuan dan ketaatan atas dasar Ketuhanan.

Berbagai teori kapital spiritual diatas, kapital spiritual bisa sederhanakan sebagai pengetahuan dan penghayatan spiritual dari suatu tradisi keagamaan yang dimiliki oleh pemeluknya. Sebenarnya spiritualitas dan religiusitas memiliki keterkaitan yang cukup erat. Oleh karena itu, peneliti cenderung mengaitkan kapital spiritual dengan kapital religius, dimana ia terkait dengan makna, nilai, dan tujuan mendasar agama.

Penggunaan istilah kapital spiritual yang dikaitkan dengan multikultural mengandaikan bahwa multikulturalisme merupakan spiritualitas. Seseorang yang menghargai keragaman yang melekat pada diri orang lain dapat melihat sumber yang unitif. Ikatan unitif ini menembus semua fenomena keragaman ciptaan Tuhan. Ikatan unitif ini disebut "Satu Tuhan". Dengan keyakinan bahwa "Satu Tuhan," maka tidak ada asal-usul segala sesuatu, termasuk realitas kehidupan yang beragam, kecuali dari Tuhan. Visi kesatuan ini memungkinkan mereka untuk melampaui

${ }^{11}$ Chris Baker and Hannah Skinner. "Faith in Action: The Dynamic Connection between Spiritual and Religious Capital," dalam Final Report of The William Temple Foundation's Research Project, (2002- 2005), 2006, 4

${ }^{12}$ Chris Baker and Hannah Skinner. "Faith in Action.., 5.

${ }^{13}$ Danall Zohar and Ian Marshall. Spiritual Capital: Wealth We Can Live. (San Francisco: Berrett-Koehler Publishers, Inc, 2004), 41.

${ }^{14}$ Seyyed Hossein Nasr, Islamic Spirituality: Foundations (New York: Routledge, 2008), 25 
perbedaan keyakinan dan dogma. Dari visi inklusif ini orang-orang yang memiliki kedalaman spiritual mampu mentolerir "otherness" dari yang lain. ${ }^{15}$ Dengan demikian, kepemilikan modal spiritual yang kuat sangat kompatibel dengan penghargaan terhadap keragaman.

\section{Kapital Spiritual-Multikultural Al-Qodir \\ 1. Spiritualitas Kiai}

Mbah Masur, sapaan akrab KH. Masrur Ahmad, merupakan tipikal Kiai yang cenderung mengedepankan model keberagamaan para sufi. Jika karakteristik pesantren seringkali identik dengan konsentrasi keahlian Kiai, maka Kiai Masrur cenderung mengendepankan pola kehidupan sufistik. Konsentrasi tersebut berimplikasi pada pola pendidikan yang dijalankan di pesantren Al-Qodir.

Di awal-awal mengasuh pesantren, secara personal Mbah Masrur melakukan amalan-amalan berupa shalat sunnah sebanyak 600 rakaat dalam satu bulan sambil mengkhatamkan al-Qur'an. Shalat sunnah ini dilakukan oleh Kiai Masrur di waktu antara shalat dzuhur sampai waktu shalat ashar. Biasanya hitungan ke 600 jatuh pada hari kamis minggu terakhir setiap bulan. Setelah shalat ashar berjamaah, dilakukan acara khataman Al-Qur'an. Setelah Maghrib dilanjutkan istighasah dan doa khataman, yang diikuti dengan tasyakuran berupa makan-makan dengan model prasmanan. Khataman ini juga biasanya diikuti oleh warga sekitar pesantren. ${ }^{16}$ Kegiatan khataman tesebut masih dipertahankan sampai sekarang, namun dilaksanakan setiap kamis malam setelah maghrib. Setiap kamis itu pula, Kiai menyedikan berbagai menu makanan sebagai bentuk syukuran dan biayanya murni dari kantong pribadi Kiai.

Disamping ritual tersebut, prilaku sehari-hari Kiai juga banyak diakui oleh banyak orang, terutama para santri. Yang paling berkesan adalah perhatian Kiai dalam mengurusi orang-orang yang terlantar, seperti orang gila, pecandu narkoba, anak putus sekolah, kenalan remaja, dan pelaku kriminal lainnya. Ada banyak kisah yang dikemukakan para santri dan orang luar pesantren soal kedermawanan Kiai. Bahkan, Kiai sendiri menanggung semua makan dan kebutuhan para santrinya. Bagi santri senior (pengurus pesantren), yang akan pulang kampung, Kiai juga seringkali memberi uang saku. Uang saku ini seringkali berupa amplop yang diberi oleh tamu yang belum dibuka oleh Kiai. ${ }^{17}$

${ }^{15}$ Frithjof Schuon, Understanding Islam (Bloomington: World Wisdom, 1998), 13-18.

${ }^{16}$ Wawancara dengan KH Masrur Ahmad pada Sabtu, 7 Juli 2018

${ }^{17}$ Wawancara dengan Suyadi, Lurah Pesantren Al-Qodir, 9 Juli 2018 
Kiai berusaha menjadikan nilai sufistik sebagai basis utama dalam membentuk kesadaran multikultural santri.

Kalau saya, tentang kebersamaan, tentang perbedaan, itu bukan karena tingginya pengetahuan. Tapi karena spiritualitas. Semakin tinggi pengetahuan, terkadang suka menyalahkan orang, merasa paling benar. Semakin tinggi spiritual, semakin melebur dengan kehidupan. Semakin merasa paling tahu, semakin tidak menghormati. Itu karena pengetahuan. ${ }^{18}$

Dengan demikian, dalam pandangan Kiai, perpecahan seringkali terjadi akibat tidak adanya nilai transcendental dalam diri manusia. Jika Tuhan selalu menjadi pusat dalam kehidupan seseorang, maka manusia akan selalu bergerak menuju kepada-Nya tanpa terganggu dengan atribut-atribut perbedaan yang ada. Maka, tidak heran jika pesantren AlQodir menerapkan pendidikan yang membebaskan. Hampir tidak ada paksaan dalam menjalankan aktivitas keagamaan di pesantren.

\section{Integrasi Spiritual dan Multikultural}

Interaksi spiritual-multikultural berlanjut secara spiral ketika seseorang menjadi kompeten secara multikultural. Artinya, nilai-nilai spiritual dapat berkontribusi membantu seseorang menjadi kompeten secara multikultural. Di pesantren Al-Qodir, spiritualitas sama-sama memiliki relevansi dengan sikap seseorang terhadap realitas multikultural, namun implementasi nilai spiritual sebagai multikulturalisme lebih terasa mengakar di pesantren Al-Qodir.

Multikulturalisme di pesantren Al-Qodir terutama dibangun berdasarkan kekuatan spiritual Kiai. Ia bersifat integral, karena sikap multikultural yang ditampilkan adalah manifestasi dari sikap spiritual Kiai. Dalam pandangan Kiai, spiritualitas yang kokoh cenderung lebih terbuka kepada semua golongan. Jika orang beribadah secara tekun dengan memegang prinsip agamanya, namun pada saat yang sama ia mengolok-olok kelompok yang berbeda, maka ibadahnya tidak dibangun diatas dasar spiritualitas yang kokoh.

Integrasi spiritual-multikultural juga tampak dari slogan Pesantren Al-Qodir, yakni "pesantren Al-Qodir menembus batas". Slogan tersebut ingin menegaskan bahwa pesantren tersebut melintasi batas-batas kultural, bahkan agama. Dalam pergaulannya, ia tidak dibatasi oleh sekat-sekat kultural dan teologis, apalagi sosiologis, sehingga ia terbuka terhadap siapapun. 
Pesantren yang menggunakan slogan menembus batas ini sebenarnya ingin melampaui segala batas-batas yang menghalanginya menuju tangga spiritual, karena dalam menggapai puncak spiritual, seseorang semestinya tidak terganggu dengan segala bentuk perbedaan. Jika seseorang masih terganggu dengan adanya orang yang berbeda, maka sebenarnya ia kehilangan konsentrasinya kepada Tuhan. Jangankan terhadap agama yang berbeda, terhadap orang yang memusuhinya sekalipun ia tidak merasa terganggu. Dalam tasawuf, spiritualis justru berusaha berlaku baik tehadap siapapun, bahkan terhadap orang yang memusuhinya.

Secara khusus, sebagaimana analisis Hall, spiritualitas dapat dilihat sebagai makna, refleksi diri, pengetahuan mistis, emosi, moralitas, agama, ekologi, dan kreativitas. Melihat lebih dalam ke delapan pendekatan ini tentang bagaimana spiritualitas dapat dipraktikkan dalam pendidikan, masing-masing menekankan gagasan tentang hubungan: with self (Habl min Allah), with others (Habl mi an-Nas), and with the world (Habl mi al-'Alam). ${ }^{19}$

Dengan menjadikan spiritualitas sebagai makna, pembentukan santri multikulturalis dapat didasarkan pada kepedulian manusia yang abadi yang merupakan domain alami dari kecerdasan eksistensial. Dengan spiritualitas sebagai refleksi diri, pesantren dapat menciptakan ruang bagi santri untuk mempertimbangkan, menetapkan, dan memantau tujuan kehidupan emosional, intelektual, perilaku, relasional, dan kegiatan secara personal. Dengan spiritualitas sebagai pengetahuan mistis, pesantren dapat membimbing para santri untuk belajar memusatkan diri, untuk terhubung dengan energi yang mencakup segala hal yang dapat memunculkan kesadaran yang lebih dalam. Dengan spiritualitas sebagai emosi, pesantren dapat menginspirasi santri untuk mengalami kekaguman emosional dan cinta untuk hidup dan rasa hormat pada semua orang yang hidup berdampingan di dunia ini. Dengan spiritualitas sebagai agama, pesantren dapat menghargai tradisi keagamaan yang dipegang secara unik oleh masing-masing pemeluknya. Dengan spiritualitas sebagai ekologi, pesantren dapat menerapkan pendidikan berbasis pengalaman, holistik, dan sensoris untuk menyoroti kemungkinan memperkenalkan santri pada pendidikan lingkungan dan "literasi ekologi" demi semua umat dimuka bumi. Akhirnya, dengan mengkonseptualisasikan spiritualitas sebagai kreativitas, pesantren berusaha menunjukkan keagungan ilahi pada diri santri dan dalam

19 Alex S. Hall, "Transformational Multicultural Spiritual Framework for Educating Youth: Spiritual Development for Children and Adolescents, Religion \& Education, 39:2, 2012, 159-171. 
interaksi dinamis mereka dengan segala makhluk hidup untuk mempromosikan kebaikan bersama.

Dengan demikian, spiritualitas dan multikultural sebenarnya tidak bisa dipisahkan satu sama lain. Ia terintegrasi karena spiritualitas secara tidak langsung juga mengandung kesadaran yang tinggi akan keberadaan makhluk Tuhan. Segala keragaman adalah bentuk manifestasi dari keagungan Ilahi. Mengakui, menyaksikan, dan mengambil hikmah keagungan Ilahi merupakan bagian dari spiritualitas yang harus dimiliki santri.

\section{Nilai-Nilai Spiritual-Multikultural}

Pendidikan multikultural selalu membicarakan nilai-nilai yang akan ditanamkan untuk melahirkan sikap multikultural. Dalam beberapa studi, nilai-nilai multikultural ini seringkali dilepaskan dari unsur pembentuknya. Padahal, nilai multikultural juga bisa lahir dari pengalaman akan penanaman nilai sebelumnya sehingga tindakan seseorang secara tidak langsung mencerminkan nilai-nilai multikultural.

Berdasarkan kajian terhadap realitas dan pengalaman yang dimiliki pesantren Al-Qodir, pesantren cenderung inklusif karena lebih mengutamakan nilai-nilai spiritual-tasawuf. Artinya terbentuknya nilainilai multikultural berangkat dari penguatan akan nilai-nilai spiritual. Nilai spiritual tersebut diantaranya, nilai kepasrahan (tawakkal), nilai keikhlasan, nilai rendah hati, nilai pelayanan (kekhalifahan), dan nilai rela berkorban. Nilai-nilai spiritual ini menjadi basis utama dalam melahirkan nilai-nilai multikultural. Dengan demikian, nilai spiritual merupakan nilai pembentuk sikap beragama yang multikulturalis.

\section{1) Nilai Tawakal (Kepasrahan)}

Nilai tawakal merupakan salah satu nilai yang dipegang dan diinternalisakan kepada santri. Ini dimulai dari sikap Kiai dalam menjalankan kehidupan sehari-hari. Tawakal adalah modal nilai utama yang dipegang Kiai sejak pertamakali mendirikan pesantren. Meski tanggungan Kiai dalam menghidupi pesantren cukup besar, tawakal adalah satu-satunya kekuatan dan modal utama.

Kesadaran semacam itu juga menjadi satu percontohan bagi para santri karena sehari-hari mereka hidup bersama Kiai. Nilai tawakal (kepasrahan) berimplikasi terhadap relasi antar agama. Ajaran kepasrahan juga mengajarkan untuk tidak menghakimi orang lain, karena segala sesuatu berasal dari Tuhan dan hanya Tuhan sebagai pemilik otoritas hidayah (petunjuk yang paling benar). Baik Kiai maupun santri tidak mampu merubah suatu keyakinan seseorang, 
melainkan hanya berusaha menampilkan kebaikan kepada orang lain, sebagaimana dikemukakan Kiai,

Saya punya prinsip "saya tidak ingin memiliki dan saya juga tidak ingin dimliki”. Begitu itu hidup. Semua ini milik Tuhan. Saya pun tidak mau digantungi apa-apa. Kalau saya dimiliki sesuatu, berarti saya diikat sesuatu.... Saya tidak merubah. Saya tidak pernah oh kamu harus begini. Jadi begitu. Saya pasrahkan gitu saja. Karena saya tidak mampu. Saya mengantarkan. Ya Allah ini milik Anda Ya Allah. Kata orangorang mereka rusak, tolong Ya Allah anda patahkan perkataan mereka. Biar Tuhan sendiri yang merubahnya. ${ }^{20}$

Pernyataan tersebut hampir sama dengan ungkapan Junaid, sebagaimana dikutip Schimmel, ketika mendifinisikan tasawuf. Menurutnya, tasawuf berarti tidak memiliki apapun dan tidak dimiliki apapun. ${ }^{21}$ Ajaran kepasrahan yang ditekankan dalam sistem nilai pesantren Al-Qodir juga menjadikan para santri tidak mudah menghakimi kelompok yang berbeda. Bagi para santri, perbedaan kultural bahkan agama mestinya dikembalikan kepada Tuhan, karena Dia-lah pemilik otoritas tunggal kebenaran.

\section{2) Keikhlasan}

Nilai spiritual yang berupa ikhlas ini menjadi modal penting dalam membangun nilai-nilai multikultural di pesantren Al-Qodir. Bahkan, bisa dikata, nilai keikhlasan juga merupakan bangunan nilai multikultural yang sangat menonjol ketika mengkaji pesantren AlQodir. Tanpa keikhlasan orang akan mengharapkan imbalan. Beberapa kali penyelenggaraan kegiatan lintas budaya dan agama di pesantren tidak pernah disisipi kepentingan-kepentingan pragmatis jangka pendek. Pesantren menyelenggarakan tersebut dalam rangka menjalin hubungan harmonis, tanpa harus menagih harapan dan pujian.

Nilai keikhlasan yang dipegang pesantren, terutama ditunjukkan oleh Kiai, merupakan satu modal nilai penting untuk membangun sikap multikultural. Multikulturalisme yang terbentuk dari nilai ini bisa melahirkan multikulturalisme tanpa pamrih: satu bentuk multikulturalisme bukan sekedar selebrasi atau sekedar momentum untuk mengisi dan turut merayakan wacana multikultural, melainkan karena hasil dari kesadaran dan keikhlasan dalam menjalin hubungan dengan siapapun.

\footnotetext{
${ }^{20}$ Wawancara dengan KH Masrur Ahmad, Pada Tanggal 9 Juli 2018

21 Annemarie Schimmel, Dimensi Mistik dalam Islam (Jakarta: Pustaka Firdaus, 2000), 17
} 


\section{3) Rendah Hati}

Rendah hati juga merupankan nilai spiritual yang diajarkan di pesantren. Nilai ini ditunjukkan dengan berbagai proses yang berlangsung selama menjalin hubungan dengan siapapun. Perasaan bahwa diri kita belum tentu lebih baik daripada orang lain menjadikan santri tidak mudah terjebak pada justifikasi benar-salah dan sikap suka menyalahkan orang lain. Pandangan para santri tersebut lebih mengedepankan pada sikap koreksi diri. Karena bagi mereka, semua manusia selalu memiliki potensi bersalah, dan terminal akhir proses hidup adalah kematian. "Wahai sekalian orang-orang yang beriman, janganlah ada satu kaum di antara kamu merendahkan kaum yang lain, kalau-kalau mereka (yang dipandang rendah) itu lebih baik daripada mereka (yang memandang rendah)". (Q.S. al-Hujurat/49:11).

Penanaman nilai rendah hati tersebut tampak nyata ketika santri harus bergaul dengan santri gila, eks pecandu narkoba dan kriminalitas. Bahkan hampir tidak ditemukan mereka saling menyalahkan karena kurangnya pemahaman agama. Parameter yang paling Nampak ketika salah satu santri mempertegas, "wong edan wae ditrimo, opo maneh wong liyo." 22 Jika orang gila diterima dengan senang hati, apalagi manusia lain yang normal meski berbeda kultur dan keyakinan.

Nilai tersebut berimplikasi pada nilai multikultural karena dengan melihat dirinya sebagai bukan satu-satunya yang paling benar, santri cenderung lebih inklusif dan toleran. Sikap inklusif dan toleran tersebut terbentuk karena kesadaran yang tinggi akan konsep diri, yang tidak mudah menganggap dirinya paling religius dan paling benar.

\section{4) Pelayanan}

Salah satu nilai spiritualitas yang melekat di pesantren AlQodir adalah nilai yang diterjemahkan dari QS. Al-Baqarah ayat 30, yakni nilai pelayanan (kekhalifahan). Pelayanan ini merupakan pelatihan bagi santri untuk memiliki sikap kepedulian yang tinggi. Penanaman nilai pelayanan sosial yang dibiasakan di lingkungan pesantren tidak terlepas dari pandangan dan tindakan yang dilakukan Kiai. Sebagaimana yang diungkapkan Kiai,

Saya ini sebisa mungkin menjadi pelayan Allah. Belajar pelayanan. Saya ini kan sesuai ayat Inni Ja'ilun Fil Ardhi Khalifah. Saya jadi khalifah. Saya yakin, saya ingin gaji yang lebih banyak dari Allah. Kalau semakin banyak pelayananku,

\footnotetext{
${ }^{22}$ Wawancara dengan Suyadi, Lurah Pesantren Al-Qodir, 9 Juli 2018
} 
semakin banyak gajiku.... Siapapun. Semua manusia. Jangankan Cuma beda agama, orang gila pun saya terima. Selama dia masih manusia, ya saya semampu saya, saya layani). ${ }^{23}$

Dalam tasawuf, pelayanan merupakan salah satu jalan spiritual yang penting. Sebagaimana yang dikemukakan Frager ketika mengkaji psikologi sufi, tasawuf adalah jalan spiritual yang dapat mengantarkan seseorang menuju persatuan dengan Yang Tak Terbatas, dan salah satu jalannya adalah pelayanan. ${ }^{24}$ Ketika manusia melayani satu sama lain, manusia juga melayani unsure ilahiah di dalam diri mereka.

\section{5) Rela Berkorban}

Salah satu nilai yang dijunjung tinggi di Pesantren Al-Qodir adalah rela berkorban. Rela berkorban ini merupakan nilai spiritual yang diterapkan secara inheren dalam setiap aktivitas pesantren. Salah satu bentuk yang paling konkrit bahwa semua kebutuhan makanan pokok santri ditanggung oleh Kiai. Meski sebenarnya uang makan tidak ditarif oleh pesantren, namun ada inisiatif dari para santri sendiri untuk iuran per bulan 60 ribu. ${ }^{25}$ Iuran tersebut sebenarnya sangat tidak cukup karena tidak ada batasan berapa kali makan dalam sehari. Ada yang sehari makan 3-4 kali terserah santri, dan mereka pun mengambil sendiri di dapur.

Beberapa penanaman nilai rela berkorban yang inheren di dalam akvitas sehari-hari tersebut meluas tidak hanya kepada internal pesantren. Beberapa komunitas di luar pesantren, baik muslim dan non-muslim juga ikut merasakan. Setiap ada kegiatan lintas agama, pesantren tidak pernah menarik biaya dan menerima uluran tangan. Bahkan, semua tamu dari non-muslim dijamu secara mewah dan prasmanan dengan berbagai menu makanan yang bervariasi. Semua menu yang disajikan merupakan hasil dari keterampilan memasak, mulai dari soto, bakso, tongseng, dan beberapa masakan sayur.

Ini merupakan suatu pemahaman penting bahwa menjalin komunikasi dan berhubungan dengan beragam agama secara harmonis membutuhkan pengorbanan, baik material maupun non-material. Rela berkorban juga dapat melahirkan sikap spiritual-multikultural yang sangat aktif. Aktif dalam pengertian tidak hanya menerima kenyataan

${ }^{23}$ Wawancara dengan Mbah Masrur, pada hari sabtu 7 Juli 2018

24 Robert Frager, Psikologi Sufi untuk Transformasi Hati, Jiwa dan Ruh, terj. Hasmiyah Rauf (Jakarta: Penerbit Zaman, 2014), 44-49.

${ }^{25}$ Wawancara dengan Suyadi, Lurah Pesantren Al-Qodir, 9 Juli 2018 
multikultural, melainkan berusaha secara partisipatif untuk membangun sikap multikulturalisme. Berangkat dari pemahaman bahwa "beragama adalah melayani," ada satu bangunan spiritual yang dibentuk bahwa hidup adalah pengorbanan. Buah dari pengorbanan tersebut adalah kebahagiaan di akhirat. Ini merupakan inti dari ajaran spiritualitas-sufistik. Dalam banyak hal, ajaran semacam ini memungkinkan terbukanya ruang yang lebih luas.

\section{Tujuan Beragama}

Perspektif pesantren Al-Qodir, terutama perspektif Kiai, sebenarnya mengambarkan perspektif mengenai tujuan hakiki orang beragama. Ini sangat berkaitan dengan komponen utama dalam pembahasan mengenai kapital spiritual. Perpektif mengenai tujuan beragama ini banyak dituangkan oleh Kiai dalam karyanya yang berjudul "Tauhid Kemanusian". Lahirnya buku ini merupakan penghayatan dan perenungan kiai dalam memahami tujuan yang sebenarnya sebagai orang beragama.

Sebagaimana yang dituangkan dalam karyanya, tauhid kemanusiaan mengajak seluruh lapisan dan status sosial yang berbeda untuk memahami hakikat diri masing-masing. Tauhid kemanusiaan memberikan kesadaran bahwa apapun kedudukan manusia di dunia, baik sebagai pengusaha, agamawan, kaum intelektal, maupun orang awam, harus diajak berpikir untuk melaksanakan tanggungjawab masing-masing sebagai makhluk sosial yang berbeda-beda sekaligus melaksanakan tugas bersama sebagai hamba Tuhan. Di hadapan manusia, kita berbeda. Di hadapan Tuhan kita sama. ${ }^{26}$

Pemikiran dan kesadaran kiai tersebut juga dibuktikan dengan beberapa prilaku yang mencerminkan perhatiannya pada tanggung jawab sosial. Bukti dari tanggung jawab sosial ini banyak disebutkan penulis ketika membahas mengenai nilai-nilai spiritual. Namun, kaitannya dengan keragaman, perhatian kemanusiaan yang ditunjukkan oleh Kiai dan santri mencerminkan perhatiannya yang menembus batasbatas kultural dan bahkan teologis. Apapun agama yang dianut seseorang, Kiai tidak pernah mempersoalkan. Selama mereka memerlukan bantuan, Kiai selalu memberikannya dengan sangat terbuka. Beberapa aktivitas sosial yang dilakukan bersama dengan komunitas lain, akan diperkuat dalam pembahasan mengenai kapital sosial-multikultural.

\section{Tabel 4.1. Kapital Spiritual-Multikultural Pesantren Al-Qodir}

${ }^{26}$ Pemikiran Kiai Masrur yang dituangkan dalam bukunya, KH. Masrur Ahmad, Tauhid Kemanusiaan (Yogyakarta: Pustaka Pesantren, 2018) 
PESANTREN MENEMBUS BATAS (Studi Kapital Spiritual-Multikultural Pesantren Al-Qodir dalam Membentuk Santri Multikulturalis ) (Sauqi Futaqi)

\begin{tabular}{|c|c|c|c|c|}
\hline No & $\begin{array}{c}\text { Komponen } \\
\text { Kapital } \\
\text { Spiritual- } \\
\text { Multikultural }\end{array}$ & $\begin{array}{c}\text { Basis } \\
\text { Spiritual- } \\
\text { Multikultural }\end{array}$ & $\begin{array}{c}\text { Implikasi } \\
\text { Multikulturalisme }\end{array}$ & Kesimpulan \\
\hline 1. & $\begin{array}{l}\text { Spiritualitas } \\
\text { Kiai }\end{array}$ & $\begin{array}{l}\text { Sufi sebagai } \\
\text { Model }\end{array}$ & $\begin{array}{l}\text { Spiritualis- } \\
\text { Multikultural }\end{array}$ & $\begin{array}{l}\text { Multikulturalisme } \\
\text { sebagai } \\
\text { spiritualitas }\end{array}$ \\
\hline 2. & $\begin{array}{l}\text { Interaksi } \\
\text { Spiritual dan } \\
\text { Multikutural }\end{array}$ & $\begin{array}{l}\text { Tauhid } \\
\text { Kemanusiaan }\end{array}$ & $\begin{array}{l}\text { Pendidikan sufistik } \\
\text { untuk membentuk } \\
\text { kesadaran } \\
\text { multikultural }\end{array}$ & $\begin{array}{l}\text { Multikulturalisme } \\
\text { sebagai } \\
\text { spiritualitas }\end{array}$ \\
\hline \multirow[t]{5}{*}{3.} & \multirow[t]{5}{*}{$\begin{array}{l}\text { Nilai-nilai } \\
\text { Spiritual }\end{array}$} & Tawakkal & $\begin{array}{l}\text { Keragaman sebagai } \\
\text { otoritas Tuhan }\end{array}$ & \multirow{5}{*}{$\begin{array}{l}\text { Nilai spiritual } \\
\text { sebagai } \\
\text { pembentuk nilai } \\
\text { multikultural }\end{array}$} \\
\hline & & Rendah hati & $\begin{array}{l}\text { Tidak merasa paling } \\
\text { benar dengan yang } \\
\text { berbeda }\end{array}$ & \\
\hline & & Keikhlasan & $\begin{array}{l}\text { Multikulturalisme } \\
\text { tanpa pamrih }\end{array}$ & \\
\hline & & Pelayanan & $\begin{array}{l}\text { Beragama adalah } \\
\text { melayani umat } \\
\text { manusia dengan } \\
\text { segala keragamannya }\end{array}$ & \\
\hline & & Rela Berkorban & $\begin{array}{l}\text { Mengorbankan } \\
\text { tenaga, pikiran, dan } \\
\text { harta kepada siapapun } \\
\text { yang membutuhkan, } \\
\text { tanpa memandang } \\
\text { perbedaan. }\end{array}$ & \\
\hline 4. & $\begin{array}{l}\text { Tujuan Hidup } \\
\text { Beragama }\end{array}$ & $\begin{array}{l}\text { Tauhid } \\
\text { Kemanusiaan }\end{array}$ & $\begin{array}{l}\text { Beragama adalah } \\
\text { menebar kebaikan } \\
\text { kepada semua umat } \\
\text { manusia }\end{array}$ & $\begin{array}{l}\text { Multikulturalisme } \\
\text { sebagai salah satu } \\
\text { tujuan beragama }\end{array}$ \\
\hline
\end{tabular}

\section{Kapital Spiritual-Multikultural dan Model Pendidikan Sufistik}

Fenomena kapital spiritual-multikultural di pesantren tersebut sejalan dengan tipe penyebaran Islam di Indonesia. Bahkan, masyarakat Indonesia mempunyai legitimasi historis yang sangat menguntungkan, karena masuknya Islam ke Indonesia tidak ditempuh melalui jalan 
kekerasan, ${ }^{27}$ melainkan dengan jalan dakwah persuasif dan akomodatif. Bahkan, Martin van Bruenessen menyebut Islam Indonesia sebagai Islam dengan wajah tersenyum. Islam yang moderat cenderung tertarik pada renungan-renungan sufistik. ${ }^{28}$ Ini menandakan bahwa Islam ekstrimis pada dasarnya kontraproduktif dengan nalar sufistik dan konteks keislaman di Indonesia. $^{29}$

Dalam konteks pesantren, Martin van Brunessen juga menyimpulkan hal serupa. Menurutnya, tradisi pesantren cenderung bercorak tasawuf dan ubudiyah. Banyak Kiai yang mengajarkan ibadah dan amalan-amalan sufistik. Bahkan, seperempat dari hasil karangan ulama-ulama tradisonal terdiri dari kitab-kitab tasawuf dan akhlak. ${ }^{30}$

Jika ditarik dalam konteks pesantren Al-Qodir, spiritualitas yang berakar daru tradisi tasawuf dipraktekkan melalui sikap keteladanan Kiai. Keteladanan tersebut merupakan model pendidikan sufistik yang menjadi contoh bagi para santrinya. Hampir semua model pendidikan di Al-Qodir diterapkan dengan menggunakan pendekatan ahwal (ilmu rasa) karena dengan begitu akan muncul rasa empati, kasih sayang, dan penuh perhatian. Metode semacam itu terbukti mampu mengakomodasi berbagai perbedaan, baik pada internal pesantren, terutama para santri, maupun eksternal pesantren, terutama berbagai komunitas agama dan budaya.

Fenomena tersebut juga bisa bisa menambahkan terminologi baru bagi teori kapital spiritual dan pendidikan Islam multikultural. Konsep kapital spiritual-multikultural mencoba menggabungkan antara konsep kapital spiritual dengan konsep multikultural. Jika kapital spiritual selama ini diorientasikan pada internal individu maupun kelompok, maka kapital spiritual-multikultural memungkinkan terbentuknya spiritualitas yang menembut batas-batas kultural dan agama. Hal ini juga ingin memecahkan kebuntuhan spiritual dimana masing-masing kelompok menunjukkan sisi elitisme spiritual dan secara ekslusif menolak spiritualitas yang lain, sehingga memunculkan fanatisme kelompok yang saling mengklaim otentisitas spiritualnya.

27 Azyumardi Azra, Jaringan Ulama Timur Tengah dan Kepulauan Nusantara Abad XVII dan XVIII (Jakarta: Prenada Media, 2005), 2

28 Martin van Bruinessen (2011), "What happened to the smiling face of Indonesian Islam? Muslim intellectualism and the conservative turn in post-Suharto Indonesia", dalam RSIS Working Papers, No. 222, volume RSIS Working Papers, No. 222

29 Sauqi Futaqi, "Nalar Sufistik Islam Nusantara dalam Membangun Perdamaian". Dar el-ilmi : Jurnal Studi Keagamaan, Pendidikan Dan Humaniora 5 (2), 2008. 1-15.

30 Martin van Brunessen, Kitab Kuning, Pesantren dan Tarekat, (Yogyakarta: Gading, 2012) edisi revisi, 88 
Terminologi tersebut tentu saja bukan hal yang dipaksakan. Jika dilihat dari fenomena yang terjadi, justru multikulturalisme merupakan bagian inheren dari spiritualitas. Bahkan, sebagaimana Frager, tradisi multikultural juga merupakan tradisi yang menonjol dalam dunia tasawuf. Tasawuf tidak pernah menjadi spiritualitas kaum elit. Yang penting adalah kualitas hati, bukan penampakan lahiriah, pakaian dan uang. ${ }^{31}$ Sebagaimana yang menjadi karakteristik pesantren Al-Qodir, spiritualitas tersebut bukan menjadi konsumsi internal pesantren, tetapi juga dirasakan buahnya bagi komunitas lain yang berbeda kultur dan keyakinan, sehingga tepat sekali jika terminologi kapital spiritual-multikultural digunakan untuk mengembangkan teori kapital spiritual.

\section{Kapital Spiritual-Multikultural dan Santri Multikulturalis}

Kapital spiritual pesantren Al-Qodir di atas sebenarnya secara tidak langsung menggambarkan proses pembelajaran multikultural di pesantren. Kapital spiritual-multikultural memberikan pengalaman belajar santri tentang nilai-nilai spiritual dan bagaimana memahami dan manghayati tujuan utama orang beragama. Ini juga memperlihatkan pola pendidikan sufistik di pesantren, dimana pola pendidikan sufistik menjadi karakteristik yang khas di pesantren $\mathrm{Al}$-Qodir.

Dilihat dari komponennya, beberapa kapital spiritual-multikultural tersebut juga sangat berkaitan dengan pengetahuan, sikap, dan tindakan multikultural.

a. Pengetahuan Multikultural

Kapital spiritual-multikultural di Al-Qodir dalam beberapa hal juga sangat terkait dengan proses pembentukan santri pada aspek pengetahuan multikultural. Ini terutama karena adanya keterbukaan. Beberapa kegiatan yang dilakukan, seperti dialog, karnaval pedamaian, saling berkunjung, saling menghadiri undangan, dan kerjasama dalam aksi sosial memberikan pengetahuan multikultural yang cukup banyak.

Jalinan relasi dan keakraban antara santri dengan komunitas lain juga secara tidak langsung terjadi sharing pengetahuan di antara mereka. Intensitas perjumpaan dan kerjasama menambah pengetahuan akan kehidupan beragama mereka. Ini satu materi penting dalam pembelajaran di pesantren, yang tidak terdapat dalam struktur kurikulum pesantren. Ditambah lagi, ada beberapa karya Kiai yang biasanya digunakan sebagai bahan bacaan santri, diantaranya seperti buku yang berjudul; 1) Tauhid Kemanusiaan (2018); 2) Islam Hijau: Mendayung Kebersamaan dalam Keberagaman (2016); 2) Islam Hijau: Merangkul Budaya dan

${ }^{31}$ Robert Frager, Op.Cit,. 43 
Menyambut Kearifan Lokal (2014); 3) Islam Hijau: Refleksi Keagamaan dan Kebangsaan NU (2014). Karya Kiai ini juga memberikan pengetahuan santri terkait perspektif Islam dalam memandang keragaman. Pandangan multkultural yang berciri khas ajaran sufistik ini menunjukkan adanya kaitan antara kapital spiritual dengan pengetahuan multikulturalisme sufistik.

b. Sikap Multikultural

Kapital spiritual-multikultural pesantren Al-Qodir semakin berkaitan erat dengan dengan pembentukan sikap multikultural. Perasaan dan sikap multikultural terutama sangat terkait dengan kapital spiritualmultikultural. Ini terutama pada pandangan "tauhid kemanusiaan" yang merupakan menjadi model dalam menghayati realitas keragaman. Disamping itu, pendidikan sufistik juga menjadi ciri khas yang menonjol. Pendidikan model ini cenderung inklusif karena tidak begitu mempersoalkan aspek-aspek yang bersifat lahiriah (eksoteris).

c. Bertindak Multikultural

Beberapa kapital spiritual-multikultural pesantren Al-Qodir juga merupakan basis utama dalam membentuk prilaku dan tindakan multikultural. Proses ini merupakan bagian yang penting karena sudah mengarah pada tindakan praktis seseorang. Dalam konteks pesantren AlQodir, kapital spiritual memberikan penekanan pada sikap spiritual yang kuat sehingga terbuka untuk berdialog dan kerjasama dengan lintas kultur. Dengan demikian, ada satu temuan penting bahwa multicultural behavior bisa terbentuk karena adanya kapital spiritual-multikultural yang kuat. 


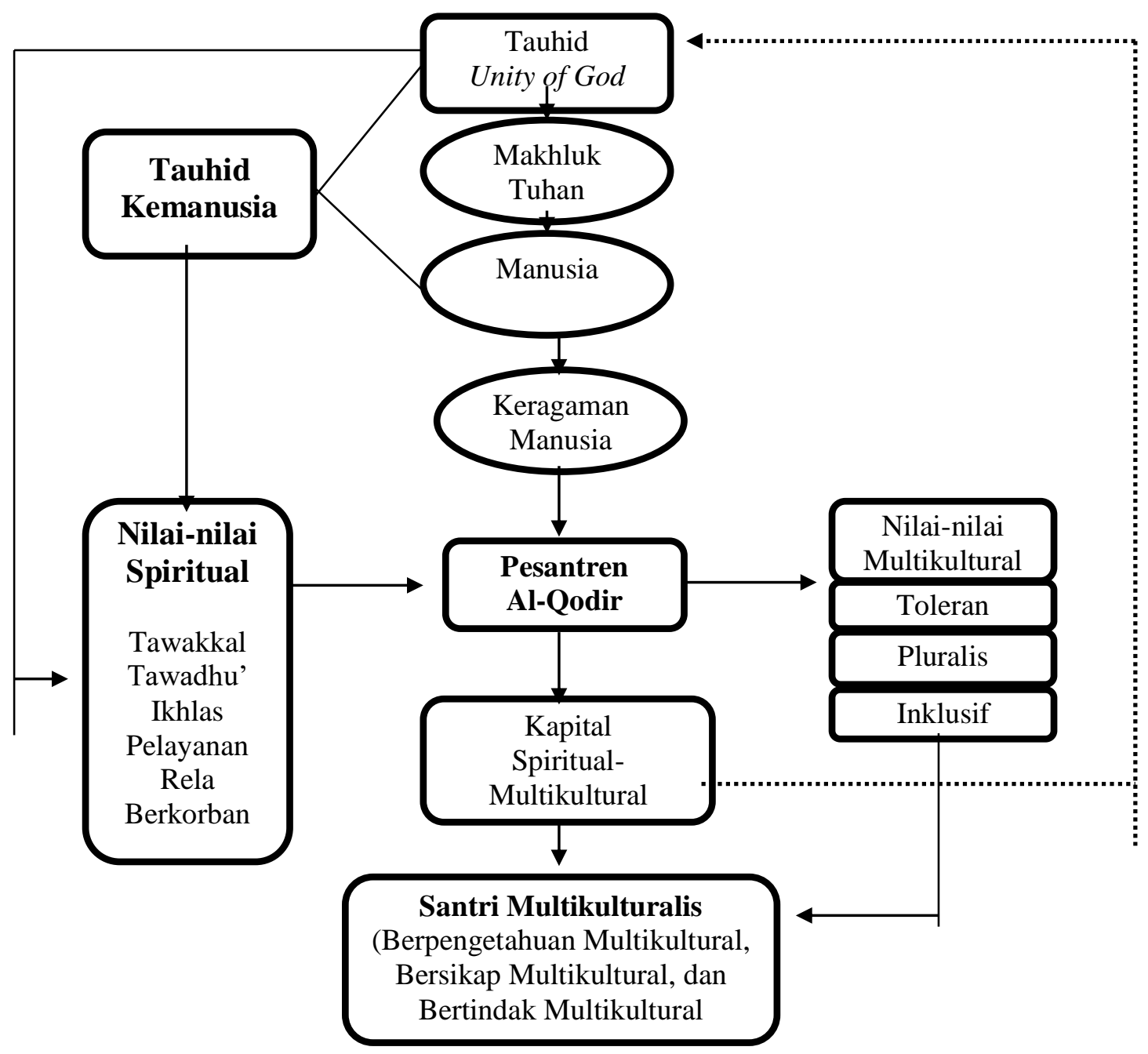

\section{Gambar 1: Kapital Spiritual-Multikultural Membentuk Santri Multikulturalis}

\section{KESIMPULAN}

Pesantren al-Qodir merupakan tipe pesantren yang cenderung menonjolkan pada aspek spiritualitas. Spiritualitas yang ditekankan di alQodir ditunjukkan dengan model pendidikan yang menggunakan pendekatan ahwal (rasa/hati). Pendekatan ini mengandaikan bahwa santri dididik tidak hanya menguasai materi, tetapi juga menerapkannya dalam aktivitas sehari-hari di pesantren. 
Dengan pendekatan ahwal dan ilmu hikmah, pesantren menitikberatkan pada penanaman kesadaran. Hampir tidak ada paksaan dalam proses pendidikan. Sebagai proses penyadaran, pesantren cenderung mengedepankan metode pembiasaan dan keteladanan. Hal ini dilakukan karena santri memiliki latar belakang yang beragam, sehingga metode penyadarannya pun beragam, mengikuti karakteristik santri. Pendekatan ahwal juga tampak dalam apresiasinya terhadap tingkah laku keseharian. Menurut standar pesantren ini, kesuksesan beragama bukan terletak pada seberapa jauh ia menguasai ilmu-ilmu keislaman, melainkan seberapa jauh ia mampu menerapkan nilai-nilai keislaman di dalam kehidupan.

Kapital spiritual tersebut melahirkan "multikulturalisme sufistik" karena didasari oleh nilai-nilai spiritual yang digali dari khazanah sufistik atau tasawuf, terutama nilai tawakal, rendah hati, keikhlasan, pelayanan dan rela berkorban. Bagi pesantren ini, semakin tinggi spiritualitas seseorang, semakin tinggi pula sikap multikultural seseorang. Maka, pendidikan spiritual-multikultural menjadi tawaran dalam membentuk santri multikulturalis

\section{DAFTAR PUSTAKA}

\section{Buku}

Ahmad Nurcholis dan Alamsyah M Dja'far, 2015, Agama Cinta: Menyelami Cinta Agama-agama. Jakarta: PT Elex Media Komputindo.

Ali Harb, 1995, Kritik Kebenaran, diterjemahkan oleh Sunarwoto Dema. Yogyakarta: LKiS.

Alivermana Wiguna, 2014, Isu-isu Kontemporer Pendidikan Islam. Yogyakarta: Deepublish.

Danah Zohar and Ian Marshall, 2014, Spiritual Capital: Wealth We Can Live. San Francisco: Berrett-Koehler Publishers, inc

Fazlur Rahman, 1996, Tema Pokok al-Qur'an, cetakan ke-2. Bandung: Pustaka.

Frithjof Schuon, 1993, The Transcendent Unity of Religions. Wheaton: Theosophical Publishing House.

Wisdom.

1998, Understanding Islam. Bloomington: World

Johnny Saldana, 2011, Fundamentals of Qualitative Research. Oxford: Oxford University Press.

John W Creswell, 2015, Riset Pendidikan: Perencanaan, Pelaksanaan, dan Evaluasi Riset Kualitatif dan Kuantitatif, terj. Yogyakarta: Pustaka Pelajar. 
Matthew B Miles, dan A. Michael Hubermen. 1992, Analisis Data Kualitatif: Buku Sumber Tentang Metode-Metode Baru, terj. Tjetjep Rohendi Rohidi. Jakarta: UI Press.

Matthew B Miles, A. Hubermen Michael, and Johnny Saldama, 2014, Qualitative Data Analysis: A Methode Sourcebook. Tirth Edition. Sage Publication, Inc.

M. Djunaidi Ghony \& Fauzan Almansur, 2017, Metodologi Penelitian Kualitatif, cet. Ke-2. Yogyakarta: Ar-ruz Media.

Muhmmad Tholhah Hasan, 2015, Ahlussunnah Wal-Jamaah: dalam Persepsi dan Tradisi NU. Jakarta: Lantabora Press.

Murtadho Muthahhari, 1985, Fundamental of Islamic Thought. Bandung:Mizan Press.

Peter L Berger and Gordon Reading, 2010, The Hidden Form of Capital: Spiritual Influences in Societal Progress. London dan New York: Anthem Press.

Robert Frager, 2014, Psikologi Sufi untuk Transformasi Hati, Jiwa, dan Ruh, terj. Hasmiyah Rauf. Jakarta: Penerbit Zaman.

Seyyed Hossein Nasr, 2008, Islamic Spirituality: Foundations. New York: Routledge.

\section{Jurnal, Makalah, Internet}

Chris Baker and Hannah Skinner, 2006, "Faith in Action: The Dynamic Connection between Spiritual and Religious Capital," dalam Final Report of The William Temple Foundation's Research Project, (2002-2005).

Daniel Sousa, "Validation in Qualitative Research: General Aspects and Specificities of the Descriptive Phenomenological Method," dalam Qualitative Research in Psychology, 11:211-227, 2014.

David A Palmer. and Michele Wong, "Clarifying the Concept of Spiritual Capital," Prepared for the Conference on the Social Scientific Study of Religion The Chinese University of Hong Kong, 10-13 July 2013.

Peter L Berger, and Robert W Hefner. 2003, "Spiritual Capital in Comparative Perspective," Conference Paper, Diakses pada tanggal 32018 Maret dari http://www.metanexus.net/spiritual_capital/pdf/Berger.pdf 